\title{
Symbolising salvation: A semiotic analysis of the church as a transformative communication system in the world
}

\begin{tabular}{|c|c|}
\hline \multicolumn{2}{|c|}{$\begin{array}{l}\text { D. Andre van Rheede van } \\
\text { Oudtshoorn }{ }^{1}\end{array}$} \\
\hline \multicolumn{2}{|c|}{$\begin{array}{l}\text { Affiliation: } \\
{ }^{1} \text { Department of Practical } \\
\text { Theology, Perth Bible College, } \\
\text { Australia }\end{array}$} \\
\hline \multicolumn{2}{|c|}{$\begin{array}{l}\text { Correspondence to: } \\
\text { Andre van Oudtshoorn }\end{array}$} \\
\hline \multicolumn{2}{|c|}{$\begin{array}{l}\text { Email: } \\
\text { andre@pbc.wa.edu.au }\end{array}$} \\
\hline \multicolumn{2}{|c|}{$\begin{array}{l}\text { Postal address: } \\
1 \text { College Court, Karruinyup } \\
6030 \text {, Australia }\end{array}$} \\
\hline \multicolumn{2}{|c|}{$\begin{array}{l}\text { Dates: } \\
\text { Received: } 23 \text { July } 2013 \\
\text { Accepted: } 15 \text { Feb. } 2015 \\
\text { Published: } 22 \text { June } 2015\end{array}$} \\
\hline \multicolumn{2}{|c|}{$\begin{array}{l}\text { How to cite this article: } \\
\text { Van Rheede van Oudtshoorn, } \\
\text { D.A., 2015, 'Symbolising } \\
\text { salvation: A semiotic } \\
\text { analysis of the church } \\
\text { as a transformative } \\
\text { communication system in the } \\
\text { world', Verbum et Ecclesia } \\
36(1), \text { Art. \#1370, } 7 \text { pages. } \\
\text { http://dx.doi.org/10.4102/ } \\
\text { ve.v36i1.1370 }\end{array}$} \\
\hline \multicolumn{2}{|c|}{$\begin{array}{l}\text { Note: } \\
\text { The author is an Academic } \\
\text { Associate of the Department } \\
\text { of Christian Spirituality, } \\
\text { Church History and } \\
\text { Missiology in the School of } \\
\text { Humanities, University of } \\
\text { South Africa. }\end{array}$} \\
\hline \multicolumn{2}{|c|}{$\begin{array}{l}\text { Copyright: } \\
\text { ( ) 2015. The Authors. } \\
\text { Licensee: AOSIS } \\
\text { OpenJournals. This work is } \\
\text { licensed under the Creative } \\
\text { Commons Attribution } \\
\text { License. }\end{array}$} \\
\hline \multirow{2}{*}{$\begin{array}{l}\text { Read online: } \\
\text { 口幽回 }\end{array}$} & \\
\hline & $\begin{array}{l}\text { Scan this QR } \\
\text { code with your } \\
\text { smart phone or } \\
\text { mobile device } \\
\text { to read online. }\end{array}$ \\
\hline
\end{tabular}

This article considers the church from a semiotic and systems-theory perspective as a revelatory symbol of the salvation-historical acts of God for and in the world. The church, as a communicative field of encounter between God and humans as well as between humans amongst each other, creates space for symbols that may be utilised to realise further encounters. At the same time, the church also operates as a communicative symbol in her own right which may be 'read' and 'interpreted' by others. The church as an operational system is shown to generate revelatory symbols to the world through her separation from, engagement with and being directed towards the world. The church is shown to exist and operate in dynamic conflict with the world as well as with the Kingdom of God through the overcoming presence of the Holy Spirit within her. An operational communicativesystem model of the church indicates that the church is an alternating rather than alternative community, which ensures ideological relevance as well as theological difference between the church and the world.

Interdisciplinary and/or intradisciplinary implications: This article utilises insights from the fields of semiotics and systems theory within a practical-theological ecclesiology, thereby providing new perspectives on the church. The article also interacts with aspects of systematictheological ecclesiology.

\section{Introduction}

Ecclesiology, from the perspective of Practical Theology, refers to the church as a communicative symbol and an operational communicative field for the encounter between God and God's people in which particular humans act as intermediaries to facilitate this encounter (Heyns 1988:16). The church, according to this perspective, symbolises both an encountered and encounter-able field of reality for interaction between the divine and the human. ${ }^{1}$ In the church, an expectational field of reality for such an encounter is generated by believers who prayerfully place themselves within a symbolic world constructed to facilitate this encounter. Different symbolic worlds are constructed through the conscious reinterpretation by humans of what 'is' to signify alternative understandings of reality. ${ }^{2}$ Each symbolic world exists as a secondary field of reality - a linguistic or conceptual interpretation of the objective, livedthrough reality within which humanity is bodily embedded. Symbolic worlds consist of a number of signs which link to other signs to generate a stable system of signs within which to interpret reality. ${ }^{3}$

The research problem concerns the church's calling to be, and operate as, a revelatory symbol within the transformative communicative event between God and the world. Whilst there are many studies on what the church should do to communicate the gospel effectively, they often do not relate to the way in which the being of the church constitutes a communicative event between God and people. In order to ensure an alignment between the essence and the

\footnotetext{
1.Many theologians would question whether the church is the only reality field for such an encounter. Moltmann (2007:119), for instance argues that creation as a whole is in an ongoing process of becoming, striving towards a final eschatological encounter with God. In this study, I shall, however, focus more narrowly on the church as the primary field for a Christian faith-based religious encounter.

2.It is still a contentious issue whether signs do, in fact, refer to objects in a real way. For De Saussure, signs only function as part of language as a formal abstract system. 'Saussure ... is deflected by his very terminology from the whole question of the ultimate referents of the linguistic sign. The lines of flight of his system are lateral, from one sign to another, rather than frontal, from word to thing, a movement already absorbed and interiorized in the sign itself as the movement from the signifier to the signified' (Jameson 1972:32). Language as a systemic whole, what De Saussure calls langue, presents a parallel form of existence to '... whatever organized 1972:32). Language as a systemic whole, what De Saussure calls langue, presents a parallel form of existence to '... Whatever organized
structures exist in the world of reality' (Jameson 1972:33). 'Symbols are not proxy for their objects but are vehicles for the conception structures exist in the world of reality' (Jameson 1972:33). 'Symbols are not proxy for their objects but are vehicles for the conception
of objects ... In talking about things we have conceptions of them, not the things themselves; and it is the conceptions, not the things, of objects ... In talking about things we have conceptions of them, not the things themselves; and it is the conceptions, not the things,
that symbols directly mean. Behaviour towards conceptions is what words normally evoke; this is the typical process of thinking' (Langer 1951:61).

3.According to De Saussure (2013:122), language is a form and not a substance. In the case of signs, as a part of the language system,
} everything depends on their relationship to each other. 
function of the church, it is important to consider the way in which the church is theologically constituted as part of God's revelation. The aim of this article is not to respond to a specific predetermined theological problem in the praxis but to develop a new perspective on the church and her engagement with the world from which a practicaltheological ideal theory for the praxis may be constructed. This ideal theory should lead to the identification of more specific practical-theological problems inherent in the praxis of the church. This article remains a practical-theological study in as much as the approach undertaken engages with the church in the context of her practical existence in the world.

This article begins by considering the formation of the church as a theological symbol in and to the world. I shall argue that the church is a revelatory event, constituted as part of God's salvation-historical eschatological engagement with the world. The church, as a communication symbol, thus has to reflect the effects, possibilities and new understanding of reality engendered by these actions of God in the world. This directly impacts on how the church's holiness, community and mission are understood and realised within the world. The article, secondly, develops a semiotic model of the church as a communicational operational system. It is shown that a semiotic understanding of the church may provide the necessary dynamic for the church to integrate the different fields of reality within which she exists in order more successfully to become God's instrument of change in the world.

'Semiotics is the discipline devoted to the systematic study of signs, symbols and communication.' (Yelle 2012:1). It is important to, firstly, lay down a rudimentary framework for the way in which semiotics and semiotic terms will be employed in this article to develop a new perspective on the church. Interdisciplinary research has the advantage of opening new perspectives within a particular field of study. ${ }^{4}$ It also suffers from the disadvantage that the reader may lack the necessary terms and foundational assumptions of the new discipline to fully, or critically, engage with the subject matter.

\section{Signs, symbols and systems}

According to Richter (1984:84), a sign serves as a communication medium, focussing the conscious thoughts of the interpreter upon a specific designate. ${ }^{5}$ The operation of a sign, however, depends on the pragmatic relationship that exists between the interpreter and the sign. The meaning, or intention, of a sign is not objectively encapsulated within the sign but is rather formed by the way in which the sign

4.It is obvious that many of the phenomena traditionally grouped together under the category of religion have semiotic dimensions, even leaving aside the fact that they are forms of human expression, incorporating words, images and symbolic actions (Yelle 2012:1).

5.'In the Old Testament signs are mostly indices or symbols. Indices occur in the form of natural signs of orientation in time and space (e.g., "lights in the firmament" as signs "to divide the day from the night" $G$ 1:14), pr., "lghts in the firmament as signs "to divide the day from the night "Gn 1:14), prophetic signs of future events, and signs of the the day with me (... Examples of conventional symbols: "show me covenant between the people of Israel and God (e.g., circumcision, Gn 17:11; blood at the door at Passover, Ex 12:13' (Nöth 1995:382). relates to the thoughts of the interpreter. ${ }^{6}$ A sign can be said to call the contents of interpreter's consciousness to the fore. This conscious contents is, however, not simply subjective. Interpreters operate within both individual and corporate 'Zeichenbenutzenden Systeme' [sign usage systems; own translation] (Bentele \& Bystrina 1978:129), which form a broad interpretive framework within which to process and interpret signs. Signs, for their part, can only be understood in terms of their immediate relationship to other signs within a code and the mediating relationship they construct between reality and the sign-users in their interpretation of reality. ${ }^{7}$ To interpret signs, humans need to understand the code, and this they learn from the sign-utilisation systems in which they participate. Communication systems are not static but intentional, flexible, integrational and thus striving for holism. The more holistic the system, the more stable it becomes so that it operates as a symbolic world or reality in which people may live meaningfully. New information may, however, result in the formation of new symbols and the reinterpretation of existing symbols and the codes within which they function and thus, ultimately, in changes to the interpretive framework.

Signs can be divided into indexes, icons and symbols. In the literature, there is still some debate as to how each term is used, but it is safe to say that they indicate progressive levels of abstraction. ${ }^{8}$ Symbols represent the highest degree of abstraction in ideas and concepts (Bentele \& Bystrina 1978:141). Symbols have fuzzy boundaries and are able to generate communicational 'contact' amongst different signs and even across different codes and, thereby, create shared relationships or community. The church, as a communicative field of encounter between God and humans, as well as between humans amongst each other, creates space for symbols that may be utilised to realise such encounters. At the same time, the church also operates as a communicative symbol in her own right which may be 'read' and 'interpreted' by others, both inside and outside of the church. ${ }^{9}$ This article will, firstly, consider the theological dimension of the church's communicative mode of existence. This is necessary in order to understand the code engendered in the church as an interpretive system by which believers may interpret reality.

\section{According to Peirce (1958:2.227), every thought is a sign.}

7.'Semiotics is the relationships between signs and knowledge (Stam 2008:25) and refers to the study of signs which operate as an intermediate codified relationship between a designate and sign users. Ferdinand de Saussure, one of the foundational thinkers in semiotics, wanted to focus purely on signs as they function within the structure of 'langue' (language) and not parole (speech).

8.This follows the classification of Peirce (1958:2.306). An index is a sign in which the signifier is directly linked to the signified - the signified can be observed or easily inferred from the signifier. There is thus a relationship of identity. An example would be a photograph (signifier) and the place photographed (signified). (Saussure, however, did not link the signifier to the material world. For him, the signifier and the signified were both mental constructs.) According to Peirce, an icon is a sign in which the signifier resembles the signified in some ways but not completely as in a portrait. In this case there is a relationship of similarity. A symbol is a sign in which there is no direct or even indirect relationship between the signifier and the signified. Symbols a rignifier and the signified. Symbols are created arbitrarily, they need to be learned. Symbols are maintained and understood through conventions which enable interpreters to
decode the meaning of the symbol.

9.The way in which the church operates necessarily affects the way in which the church relates to those outside of the church and thus the way in which the church is 'read' by those on the outside. 


\section{The church as a theological revelatory symbol}

This section considers what it means for the church to be depicted as a revelatory or communicative symbol in and for the world. To answer this, we shall have to gain clarity on how the church is constituted theologically from a semiotic communication perspective. To do so, we shall have to contemplate (1) how the church fits in with God's revelatory acts in the world and (2) to what reality the church as a communication symbol ultimately refers.

Revelation implies signification, communication, exposure. In theology, 'revelation' most often indicates God, as a person, becoming knowable through certain actions or events. Theology and revelation are in a reciprocal relationship. There is no revelation without some form of theological processing of the revelatory event to signify it as revelation. At the same time, theology, as a believing response to revelation, is directed towards revelation and must submit to being critically tested and evaluated in the light of revelation. The relationship between revelation and theology remains asymmetrical: Theology rests upon revelation whilst revelation is the result of an event before, outside of and apart from theological reflection. Revelation rests upon the salvation-historical acts of God in, with and for the world and the working of the Spirit of God within the church to interpret these events as revelatory. Without this asymmetrical relationship, theology asserts, we are no longer dealing with theology but with philosophy. ${ }^{10}$

If this understanding of revelation and interpretation is accepted, it follows that a semiotic analysis of the church must set as its starting point the salvation-historical eschatological acts of God within, with and for his creation, revealed as such in the Word and witnessed to by the church. ${ }^{11}$ The church is constituted by the Word as one of the revelatory actions of God in the world. It is thus a communicative symbol of God's revelation within, to and for the world. The church is uniquely posited within a symbolic world and objective reality. The symbolic world is created through the Word. According to the Word, the church is the community of believers who confess their forensic incorporation in the death and resurrection of Christ. The church confesses a new understanding of reality filled with eschatological expectation, as Pannenberg (1971) says:

He has left his impression on the experiences of the world, and on the situation of man as the God of the promises, as the God who leads history into a new future, and the God of the coming kingdom. The high point of this futurization of the experience of existence came with the appearance of Jesus. Here the conviction about the nearness of the kingdom so intensified concentration on God's future that alongside this everything transmitted from the past and all present reality lost any independent meaning

10.In his On the Teacher, the first systematic work of Christian semiotics, Saint Augustine ... insightfully grasped how the flux of signs and signifying relationships in both our verbal and non-verbal communication serve no serious evangelical purpose unless they are accompanied by an awareness of the procedures by which we interpret both texts and circumstances. Our strategies of interpretation, in turn, remain rudderless without the "illumination" of the Spirit' (Raschke 2013).

11.The Word is here linked to the Biblical witness, which functions as Word of God in the faith context of the church. and God's future itself became determinative for the present. (p. 237)

Oscar Cullmann (1977), contra Pannenberg, argues as follows:

... and accordingly in an assured fact which cannot be touched by the delay of the parousia. (p. 88) (italics original)

Whilst coming to the present reality from different temporal directions, one from the future and one from the past, both Pannenberg and Cullmann emphasise that the present reality has been directly impacted by God's salvation-historical actions, culminating in the Christ event. According to Berkhof, the church comes from somewhere and is on her way to somewhere and exists to bring the point of departure and the end point together. ${ }^{12}$ God's final revelatory act, in Christ, by which God reconciled the world to himself, instituted the church as a mediating communication symbol of this event in and to the world (Nöth 1995:383). The church, as the pastoral catalyst for the encounter between God and humanity, becomes a reality through people's faith in the symbolic revelatory status of the salvation-historical events which originally established the church and the church's expectation that God will continue to encounter his people within and through the church to establish and maintain it as God's communication symbol to the world. The church is, thus, in essence a community of hopeful believers.

\section{The reality to which the church as theological symbol refers}

Semiotically, the church functions as a symbol which refers to the person and character of the triune God. Grenz (2000) puts it in the following words:

The church reflects the character of God in that it lives as a genuine community - lives in love - for as the community of love the church shows the nature of the triune God. ${ }^{13}$ (p. 483)

God is essentially holy, loving and directed towards that which is not God self. These attributes are symbolised through the Trinitarian revelatory designations of God, namely, as Father, Son and Holy Spirit. The church's symbolisation of the triune God is represented through the church's holiness, community and mission. ${ }^{14}$ These designations are not abstract, 'spiritual' symbols of the church, referring only to the church's participation by faith in the eschatological Kingdom of God. They, instead, refer to the church's concrete existence within the world. ${ }^{15}$

12.The church can be typified as an intermediary in the sense that "... de kerk ergens vandaan komt en ergens heengaat, om uitgangspunt en eindpunt te verbinden (Berkhof 2002:360).

13.Otor (2011:XIII) comments that '... the church is rooted in the Trinity both in its nature and its mission'.

14.This reflects the longer form of the Nicene Creed's reference to 'one, holy, catholic and apostolic' church (Marthaler 1993:296).

15.All three elements pertain to God as trinity. Holiness may indicate the transcended nature of God, who is supple enough in his holiness to enter into the world through Christ and the Holy Spirit. Mission refers to God sending his Son, the Son going and the Father and Son sending the Spirit. Unity refers to the inter-relational unity and the Father and Son sending the Spirit. Unity refers to the inter-relational unity
within the triune God as well as the work of the Spirit to unify believers in Christ with God. 
In theology, faith and truth are reciprocal terms. Without truth, faith can only be categorised as make-belief. Faith is epistemologically grounded in the experiential lived-through understanding of truth that characterises the Old-Testament concept of emeth as trustworthy truth. The church is, thus, founded on the confession of believers that the 'truth' of the gospel has broken into their lived-through reality, that they have found this truth to be a reliable and transformative interpretation of reality and that they have put their trust in it by operating according to it. This implies that theological symbols within the church must continue to reflect the historical rootedness of God's coming to earth to demonstrate God's continuing focus on the physical lived-through reality within which the church exists. ${ }^{16}$ The church thus also refers to sinful people in a physically determined, lived-through, broken reality in need of salvation. The reality for which the church is a communicative symbol, however, also extends beyond this lived-through reality. ${ }^{17}$ It refers to a new reality, a new age, inaugurated by Christ. Within this reality, the church participates by faith, through God's Spirit, and continues to witness through the presence of the Holy Spirit within her.

\section{Holiness}

The term holiness expresses the essential difference between the church and the world. The church is ascribed holiness on the grounds of her unity with Christ, the risen Lord, and the presence of his Holy Spirit within her. Holiness is, however, not only a status given to the church but depicts the church's differentiating presence in the world. Berkouwer (1976) notes:

Holiness is usually thought of as perfection and cleanness, the radiation of a deep striking purity; and the church has always spoken of holiness in such a way that it, in any case, has something to do with that. Theology may sometimes have spoken of the hidden holiness of the church, as Luther did, but that does not mean that there is a total misunderstanding of what the Church means by holiness here, since precisely with respect to holiness, many can understand that 'hiddenness' only with difficulty. It is not unjust that holiness is always connected with what becomes visible in the world in one way or another and can be perceived by human eyes as a light that shines in the darkness. (p. 314)

For the church to make her holiness visible requires the relevant contextualisation of the symbolic theological code to make it accessible and 'readable' to those outside of the church. This requires the church to be fully engaged with the world, to be relevant to it while simultaneously differentiating herself and setting herself apart from it. This requires suppleness from the church and a willingness to prioritise, change and adapt her modus vivendi in order to develop meaningful symbols which reflect the church's

16.The term 'lived-through reality' in this article points to the physical reality which limits humanity's freedom to do what they want. All other interpretations of reality form secondary fields of reality in that they still continue to be bound and limited by objective lived-through reality.

17.Corrington (2000:6) decries 'theologies' 'anti-naturalistic form'. Theology needs to hold to both the natural world and the alternative reality which is not radically different from that world but a symbolic re-interpretation of that world. grounding in the gracious love of God for the world as well as the church's difference from the world as constituted by her faith. 'Suppleness' may, in this sense, be seen as a necessary precondition for the church to reflect her holiness. ${ }^{18}$ Without the suppleness to change in order to set up meaningful points of differentiation from the world, the church may simply become irrelevant and old fashioned.

\section{Community}

Theologically, the concept of the church as 'community' is linked to the symbolic unity of the church, which is founded on the unity of the triune God. 'Community' points to the corporate structure of the church as the one body of Christ in the world and represents the internal life of the church. This internal community life of the church can also be designated as love.

Love expresses the contact and fusion that the theological symbols within the church generate amongst believers and between believers and God. Symbolic fusion means a transformation of the interpretive code by which people make sense of their world. Love, like holiness, implies difference and engagement. Whilst holiness primarily seeks to direct and move believers from engagement to differentiation, love directs and moves believers from differentiation to engagement. Without love, the church may easily become rigid and judgemental. Love as the inner life of the church requires believers to find each other in and through the theological symbols operating in the church and to give each other space to be different before the Lord. The love of God, which forgives sinners graciously in Christ, becomes the operative symbol regulating the believers' attitudes towards each other (1 Cor 13). It is because love is directed towards the other, in their broken world, that the church cannot be depicted as an alternative society but rather as an alternating society.

\section{Mission}

J.C. Hoedendijk (1966:52) noted that the church does not have a missionary function but that the church is a function of God's mission. According to him, the church is not '... een statische gemeenskap ..., de men kan genieten, maar een gemeenskappelijk corporatief participeren aan Christus en zijn messians werk (apostolaat) in de wereld' [... a static community ... that people can simply enjoy, but a communal corporate participation in Christ and his Messianic work (mission) to the world; own translation]. The church is directed towards the world because God is directed towards the world. According to Weber (1983:579), the church exists from and in the fact that God has not rejected the world but loves it (Jn 3:16). The church, according to him, is the document of God's love. This is the ultimate reason for the church's existence.

The church, as theological symbol to the world, must meet the world in love within their interpretive code in such a way that it both confirms and disrupts the interpretive system of

18.1 prefer to use the term suppleness rather than flexibility as the church is designated a body rather than a thing. 
the world. This means that the missionary church may not be culturally imperialistic but has to adapt to fit into each culture in order to become a theological sign to that culture. Bergman (2003) points out the following:

The situation of an increasing ethnic, religious, and cultural pluralism makes it impossible to present the faith of the church as the one and obviously universally applicable source of the whole of the social value and norm system. (p. 43)

At the same time, the mission of the church is to alter the world and its cultures in the light of the new reality in Christ. As the symbol of the Kingdom as meta-symbol, the church is called to put up signs of God's kingdom in the world. These signs are created through the obedient transformative acts of love which the church do to reflect the salvation-historical eschatological work of Christ for the world.

\section{The church as a communicative operational- interpretative system}

\section{A model of the church}

As an operational communicative system, the church can be described as a holistic inter-dependent cohort of people in an open synergistic system bound together by faith in Christ. The church also entails the resulting value system which differentiates her from her environment which is teleologically orientated and dynamically moving towards the Kingdom of God as her final goal. Simultaneously, the church is participating in the cultural, ideological and counter-Kingdom progression of a reality apart from faith.

In her historical cultural and ideological existence in and through time (diachronically), the church represents a 'segment of society'. The church is the gathering of people from multiple cultural, personal and ideological backgrounds, and all those elements are represented within her mode of being. The church, hereby, is shown to participate in the ideological progression of the world. ${ }^{19}$ The people born within a certain ideological milieu bring their ideological presuppositions into the church. Such ideological adaptation, however, also includes a sinful, counter-Kingdom disposition and interpretation of reality. In her eschatological existence towards the Kingdom of God (synchronically), the church can be described as a 'segmented society'. It is shown to be different and separated from society and directed towards the Kingdom of God. The use of the term 'eschatological' indicates that the church already participates in the coming Kingdom and shares the presuppositions of the Kingdom in interpreting reality.

Schematically the diachronic and synchronic elements may be depicted in the following way.

In Figure 1, line A-C represents society's movement through time in which its ideology is constantly changing. ${ }^{20}$ In this

19.'As such an objective cult has an ongoing history and is subject to the usual conditions of historical continuity and change. These communities have different evolving life histories and different life-spans' (Power n.d.:8).

20.'Depending on the times and social and cultural conditions, that which seems reasonable or unreasonable is no longer a forgone conclusion. History loses its normative value' (Bergmann 2003:8).

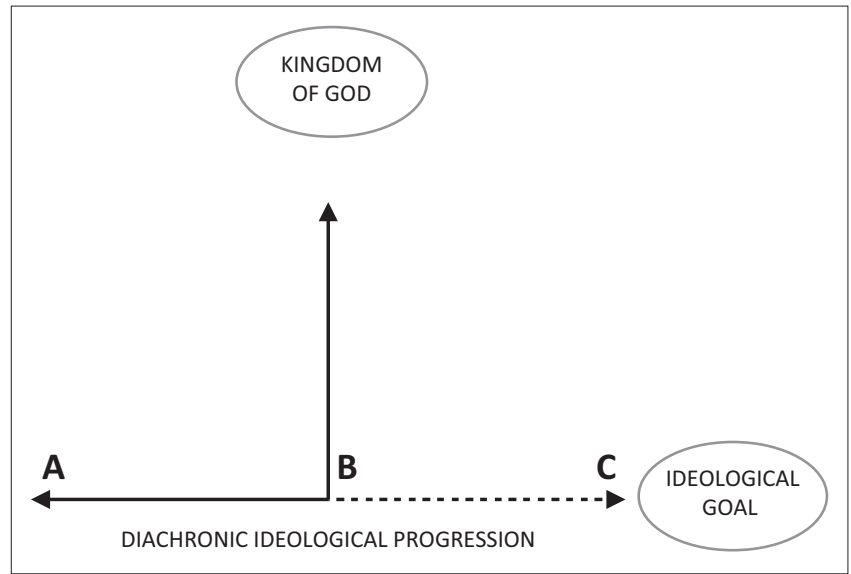

Source: Author's own creation

FIGURE 1: Diachronic and synchronic elements of the Kingdom.

sense, A-C represents an interpretation of reality. Line $\mathrm{A}-\mathrm{C}$ is also indicative of the lived-through physically determined reality in which all of humanity participates. Line B-D indicates the synchronic dimension in which the church finds herself. The church is shown to progress along the horizontal axis in the direction of her final destination - the final eschatological Kingdom of God. The synchronic axis represents a secondary field of reality. B reflects the historical point of contact between the diachronic and synchronic axes.

The church may stagnate in both her synchronic and diachronic progression. Synchronically, such stagnation may take place as a result of the initial eschatological symbols being emptied of their relevance and significance for the interpreters. This emptying takes place through cultic-ritualistic repetition within a spiritual environment or secondary field of reality created for them by the church and divorced from the diachronic lived-through reality within which the church continues to exist. ${ }^{21}$ When this happens, the symbols lose their communicative potential to disrupt and challenge the church's interpretation of reality. Such symbols become clichés which operate safely within a non-threatening expectational field created for them by the church. The expectational field, in turn, becomes narrower and narrower as symbols lose their eschatological, disruptive, transformative and communicative potential for the transformation of lived-through reality. The church's field of reality for the mediated encounter between God and humanity thereby negates the church's call to function as a communicative symbol within and to a world without faith - as indicated by the notion of conflict (B) in the model.

\section{Conflict}

'Informasie vorm die basis van elke menslike sisteem soos energie-wisseling die basis vorm in biologiese sisteme. Die gelowige en die kerk het ook deel aan hierdie wetmatigheid' [Information forms the basis of every human system in 21. Symbols represent information which is processed as energy for the system's progression along the different axes. 
the same way that the transfer of energy forms the basis for biological systems. Believers and the church also operate according to this law; own translation] (Richter 1984:10). Just as a biological system can only live when new energy is introduced regularly, the church's teleologicaleschatological progression towards the Kingdom of God can also only happen through the processing of new information within the church. New information implies the potential of the theological-eschatological symbols to generate positive, hopeful and liberating conflict between the faith dimension of the church and the ideological reality within which the church exists. ${ }^{22}$ This conflict becomes the catalyst for faithful believing actions by the church to transform the livedthrough reality into signs of the Kingdom of God. 'For the sake of the whole, the theologian becomes involved in a modern world system, which constantly forces distinctions and divisions between the living' (Bergmann 2003:26).

Scharfenberg and Kämpfer (1980:170ff.) distinguishes between two types of 'Grundkonflikte'. ${ }^{23}$ The first is internal psychological conflict such as hate, love and identity which people experience within personal relationships, and the second is external, worldly conflict which people experience in their relationship to supra-personal, corporate structures such as family, friends and political power structures. Theological symbols operating as new information within the church generate conflict with the 'Grundkonflikte' to expose the underlying ideology which informs the relational actions and relational structures. New information within the church operates to challenge all forms of ideological conformation within the church. Without this conflict, the eschatological axis becomes anachronistic rather than synchronic.

The church as theological-communicative symbol stands in conflict with other ideological symbols and codes because of the scandal of the cross and resurrection that marks her being. The cross represents an inversion of all ideological interpretations of reality because it exposes humanity as radically sinful and only fit for destruction at the hands of the Holy God of love. Humanity's continued existence (resurrection) rests solely on who God is as the One who loves humanity despite its propensity to sin. The scandal of the cross and the resurrection, however, goes deeper than a mythological exposé of humanity's need to instil hope for humanity's continued and progressive existence in future. Because it is linked to one person, Jesus Christ, who is confessed as God, humanity may not see the figure on the cross as a direct representation of itself. Christ dies as the unique human, the human different from other humans, the human who is God and who, thus, excludes other humans from identifying with this human. The Christological scandal lies therein that God identifies with us and not we with him.

22.1 concur with Bergman's (2002:23) observation: 'The word ideology has struck a negative note in recent years and some people assert that all utopias and ideologies are at death's door after the fall of the Soviet Empire. The categorical ideologies are at death's door after the fall of the Soviet Empire ... The categorical post-modernist uses the work (sic) ideology in the meaning of the way of thinking and norm system which limits the space of action of the individual. My definition of ideology joins the current definition and refers to the extensive system of norms figures of society in a larger region.'

23.'Basic' or 'primary conflicts' (own translation).
The conflict of Christ as eschatological symbol is the demand to believe in him and only him in order to participate in the church where his Spirit is present and in operation.

\section{The Holy Spirit as the generator of conflict}

The Holy Spirit is God's eschatological gift to the church through whom the living presence of the Lord becomes an existential reality within this broken world. Heyns (1978:365) argues that, whilst Christ is the objective ground for the existence of the church, the Holy Spirit is the subjective ground. This means that, if the Holy Spirit had not been given (Lk 11:13; Jn 14:6, 26; Ac 2; Gl 4:6; 1 Pt 1:12), there would not have been a church. 'Maar nou is Hy gegee en daarom is daar kerk' [But now he has been given, and therefore there is a church; own translation] (Heyns 1978:365). The Holy Spirit represents God's intentional engagement with creation to lead it to the final consummation of his rule over -all and everything. The church as theological symbol always points away from herself to the Kingdom of God as meta-symbol while confessing that the Spirit's presence within her is already realising signs of the Kingdom. The church exists in the tension between the Kingdom of God and a world in opposition to God's kingdom. The church expresses this tension through difference - it is both different from the world and different from the Kingdom. The church is simultaneously affected by the lived-through reality within which she exists ontologically and the Kingdom of God, in which she exists by faith. She is also affected by the presence of the Spirit who strives for, with and against the church to realise her 'faith existence' within, with, for and against the world.

\section{The integration of different fields of reality within the context of the church}

The Spirit continues the presence of Christ, the weak and vulnerable, who was abused and crucified in the world through his presence in the church. The Spirit also represents the resurrected Lord who has overcome death and the old reality of sin. The church therefore has to accommodate the eschatological tension between the Kingdom being 'already present' and 'not yet present' within her as embarrassment and triumph. As a communicative faith-operational system, the church incorporates both religious experiences and the absence of religious experiences. Whilst the church creates an expectational field and, thus, the opportunities for personal, corporate, sacramental and charismatic experiences of God's presence, this may never lead her to '... the illusion of invulnerability ...; a pseudo-defence against true human openness ...; a contra-reality ...; an unrealistic utopia' (Richter 1984:88). Cross and resurrection, glory and humility should be balanced as reciprocal conflict-rich terms within the communicative dimension of the church in her engagement with the world.

The church as an operational communicative system is called to codify theological symbols in such a way that they reveal (1) God, (2) God's loving commitment to humanity, (3) humanity's need before God, (4) the church as an ideological community, (5) the church as a Christologically 
determined, eschatologically transformed faith community and (6) the church as pneumatologically impacted transformative community in the world. The words of Bergman (2003) are apt here:

Each place in Creation is understood as a possible place for revelation. Each place is construed as a possible agent for cooperating with the liberating God. The Holy Spirit not only gives life to a creature in a place but also animates the space. It is especially the places which are seen as profane in a culture that attract the interest of contextual theologians. (p. 28)

As we have argued, the church represents within herself both a profane place and an expectational faith-field for the revelation of God. It is only in the context of faith that historical events on the diachronic axis are interpreted as a revelation of this particular God. It is also only through the presence of the Spirit within the church within this faithfield that the church is transformed into a loving community and becomes directed towards the broken and marginalised outside of the church. This happens whenever the church retains the awareness of her own brokenness before God and becomes willing to accept marginalisation in society for her commitment to the Kingdom of God as an alternative interpretation of reality. The dynamic integration of different interpretive fields of reality sets up the unique symbols and code which reflect the coming to and presence in the world of the triune God.

\section{Conclusion}

This article considered the semiotically constructed symbolic reality of the church as a communicative symbol. It showed that the church as a theological revelatory symbol has been generated through the salvation-historical acts of God in Christ and, thus, ultimately refers to the triune God, broken humanity within a broken world and the new age inaugurated in Christ. The church as a symbol participates in God's relevant communication to the world through her holiness, community and mission. Holiness, it has been argued, sets the church towards God's eschatological Kingdom as her goal. The church is thus characterised by differentiation. At the same time, the church needs to be flexible to reconstitute her difference within changing contexts because the dominant culture in which she finds herself continues to change through time. The church as community reflects its engagement with God, and because God is engaged with the world, it also reflects the church's missional directedness towards and loving engagement with the world. The church is not a static symbol but operates as a communicative operational system within the world. A model was developed, indicating that the church operates as an alternating rather than alternative society and that the church exists within the dynamic realm of conflict between the eschatological Kingdom and the world. It is only as the church integrates different interpretive fields of reality within herself to symbolise her commitment to the Kingdom that she is able to set up a new, alternative code which is both accessible to be read by the world and yet calls the world to the Kingdom of God as an alternative reality. The church is not only a symbol but, through the presence of the Spirit within her, continues to generate new symbols through her words and actions which participate in God's continuing, communicative, salvific commitment to the world.

\section{Acknowledgements Competing interests}

The author declares that he has no financial or personal relationships which may have inappropriately influenced him in writing this article.

\section{References}

Bentele, G. \& Bystrina, I., 1978, Semiotik: Grundlagen und Probleme, Kolhammer, Mainz.

Bergmann, S., 2003, God in context: A survey of contextual theology, Ashgate Publishing, Ltd., Burlington, VT.

Berkhof, H., 2002, Christelijk geloof, Kok, Kampen.

Berkouwer, G.C., 1976, The church, Eerdmans, Grand Rapids, MI.

Corrington, R.S., 2000, A semiotic theory of theology and philosophy, Cambridge University Press, Cambridge, New York, NY. http://dx.doi.org/10.1017/ CBO9780511487644

Cullmann, O., 1977, Christ and time: The primitive Christian conception of time and history, Gordon Press Publishers, Brooklyn, NY.

Grenz, S.J., 2000, Theology for the community of God, Eerdmans Publishing, Grand Rapids, MI.

Heyns, J.A., 1978, Dogmatiek, N.G. Kerkboekhandel Transvaal, Pretoria.

Heyns, L., 1988, 'Die plek van gemeentebou binne die Praktiese Teologie', Theologia Evangelica XXI(1), 14-18.

Hoedendijk, H.D. de, 1966, Hoedendijk en verder ..., Kok/Ten Have, Kampen.

Jameson, F., 1972, The prison-house of language: A critical account of structuralism and Russian formalism, Princeton University Press, Princeton, NJ.

Langer, S.K., 1951, Philosophy in a new key: A study in the symbolism of reason, rite and art, New American Library, New York, NY.

Marthaler, B.L., 1993, The creed: The apostolic faith in contemporary theology, Twenty-Third Publications, Ellicot City, MD.

Moltmann, J., 2007, The future of creation: Collected essays, Fortress Press, Augsburg, $\mathrm{MN}$

Nöth, W., 1995, Handbook of semiotics, Indiana University Press, Bloomington, IN.

Otor, P.A., 2011, Church: A reflection of the triune God: An introduction to Trinitarian ecclesiology, WestBow Press, Bloomington, IN.

Pannenberg, W., 1971, Basic questions in theology, vol. 2, Fortress Publishers, Augsburg, MN.

Peirce, C.S., 1958, Selected writings (Values in a universe of chance), Courier Dover Publications, Mineola, NY.

Power, W.L., n.d., Peircean semiotics, religion and theological realism, viewed 18 March 2014, from http://power.myweb.uga.edu/PDFs/Peircean\%20Semiotics, $\% 20$ Religion,\%20and\%20Theological\%20Realism.pdf

Raschke, C., 2013, 'Taking semiotics to church: A review of Crystal Downing's changing signs of truth', The Other Journal 21, Wipf \& Stock, Eugene, OR.

Richter, J.G.M., 1984, Semiotiese dimensies van die gemeente, Unisa, Pretoria.

Saussure, F. de, 2013, Course in general linguistics, Columbia University Press, New York, NY.

Scharfenberg, J. \& Kämpfer, H., 1980, Mit Symbolen leben: Soziologische, psychologische und religiöse Konfliktbearbeitung, Walter Verlag, Olten.

Stam, C.A.J., 2008, The church in relation to the world: A conceptual analysis of the church world relationship and a study of the use of performative language and discursive strategies in three documents of the World Council of Churches' Faith and Order Commission, Eburon Uitgeverij Delft.

Weber, O., 1983, Grundlagen der Dogmatik, Evangelische Verlagsanstalt, Leipzig.

Yelle, R., 2012, Semiotics of religion: Signs of the sacred in history, Bloomsbury Publishing, London. 